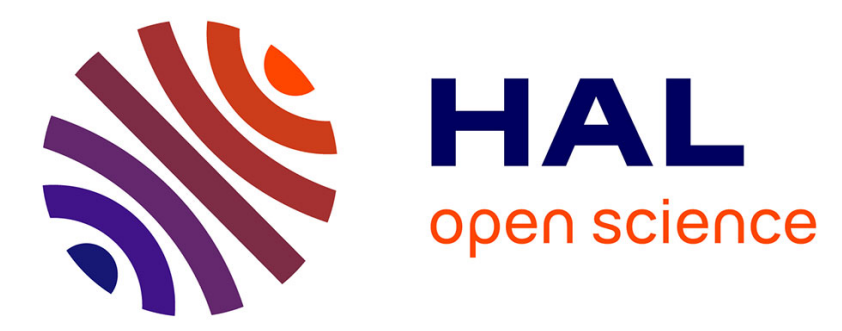

\title{
Parallel ecological filtering of ultramafic soils in three distant island floras
}

Yohan Pillon, Dubiel Alfonso González, Herizo Randriambanona, Porter P. Lowry Ii, Tanguy Jaffré, Sylvain Merlot

\section{- To cite this version:}

Yohan Pillon, Dubiel Alfonso González, Herizo Randriambanona, Porter P. Lowry Ii, Tanguy Jaffré, et al.. Parallel ecological filtering of ultramafic soils in three distant island floras. Journal of Biogeography, 2019, 46 (11), pp.2457-2465. 10.1111/jbi.13677 . hal-02284387

\section{HAL Id: hal-02284387 \\ https://hal.umontpellier.fr/hal-02284387}

Submitted on 8 Dec 2020

HAL is a multi-disciplinary open access archive for the deposit and dissemination of scientific research documents, whether they are published or not. The documents may come from teaching and research institutions in France or abroad, or from public or private research centers.
L'archive ouverte pluridisciplinaire HAL, est destinée au dépôt et à la diffusion de documents scientifiques de niveau recherche, publiés ou non, émanant des établissements d'enseignement et de recherche français ou étrangers, des laboratoires publics ou privés. 
Pillon Y., González D. A., Randriambanona H., Lowry II P. P., Jaffré T., Merlot S. 2019. Parallel ecological filtering of ultramafic soils in three distant island floras. Journal of Biogeography, 46 (11): 2457-2465.

Parallel ecological filtering of ultramafic soils in three distant island floras

Yohan Pillon ${ }^{1}$, Dubiel Alfonso González ${ }^{2}$, Herizo Randriambanona ${ }^{3,4}$, Porter P. Lowry II ${ }^{5,6}$, Tanguy Jaffré 7,8 , Sylvain Merlot ${ }^{9}$

${ }^{1}$ LSTM, IRD, INRA, CIRAD, Montpellier SupAgro, Univ Montpellier, Montpellier, France.

${ }^{2}$ Laboratorio Biotecnología Vegetal, Dpto. Biología-Sanidad Vegetal, Facultad de Agronomía, Universidad Agraria de la Habana, Autopista Nacional, Km 23 1⁄2 Carretera Tapaste, San José de las Lajas. Mayabeque. Cuba CP: 32700.

${ }^{3}$ Centre National de Recherche sur l'Environnement (CNRE), 34 rue Rasamimanana, BP 1739, Antananarivo 101, Madagascar.

${ }^{4}$ ISSEDD, BP 591, Toamasina 501, Université de Toamasina Madagascar.

${ }^{5}$ Missouri Botanical Garden, 4344 Shaw Blvd., St. Louis, Missouri 63110, U.S.A.

${ }^{6}$ Institut de Systématique, Évolution, et Biodiversité (ISYEB), Muséum National d'Histoire Naturelle/Centre National de la Recherche Scientifique/ Sorbonne Universités/École Pratique des Hautes Études, C.P. 39, 57 rue Cuvier, 75005 Paris, France.

${ }^{7}$ AMAP, IRD, CIRAD, CNRS, INRA, Univ Montpellier, Montpellier, France.

${ }^{8}$ AMAP, IRD, Herbier de Nouvelle-Calédonie, Nouméa, New Caledonia.

${ }^{9}$ Institute for Integrative Biology of the Cell (I2BC), CEA, CNRS, Univ. Paris-Sud, Université Paris-Saclay, 91198, Gif-sur-Yvette cedex, France.

Correspondence: yohan.pillon@ird.fr short running title: Ecological filtering of ultramafic soils 
Pillon Y., González D. A., Randriambanona H., Lowry II P. P., Jaffré T., Merlot S. 2019. Parallel ecological filtering of ultramafic soils in three distant island floras. Journal of Biogeography, 46 (11): 2457-2465.

\begin{abstract}
Aim: Alexander von Humboldt observed that plant communities on different continents but under similar climatic conditions shared few common species but often contained representatives of the same genera or higher taxonomic groups. To test if this observation can be extended to substrate type, we explored whether a phylogenetic signature could be seen among floras growing on ultramafic substrates that present challenging edaphic conditions for plant growth and are well-known for their distinctive vegetation.
\end{abstract}

Location: Cuba, Madagascar, New Caledonia

Taxon: Angiosperms

Methods: We compared the floras of Cuba, Madagascar and New Caledonia to test whether the same plant families were under- or over-represented on the ultramafic substrates of the three islands.

Results: Pair-wise comparisons showed that plant orders and families tended to have the same behaviour on the three islands, i.e. ultramafic substrates filtered (in favour of or against) the same plant groups in the three biogeographical distinct areas. The COM clade (comprising Celastrales, Oxalidales, and Malpighiales) appears to be over-represented on ultramafic substrates in all three islands and contains over half of the world's known nickel hyperaccumulators.

Main conclusions: Our analyses provide support for Humboldt's observation by showing that ecological sorting can favor the same plant lineages in similar environments in different biogeographical regions.

KEYWORDS: ecological filtering, disharmony, exaptation, island, niche conservatism, nickel hyperaccumulator, serpentine 
Pillon Y., González D. A., Randriambanona H., Lowry II P. P., Jaffré T., Merlot S. 2019. Parallel ecological filtering of ultramafic soils in three distant island floras. Journal of Biogeography, 46 (11): 2457-2465.

\section{1 | INTRODUCTION}

“Quand la nature n’offre pas les mêmes espèces, elle se plaît à répéter les mêmes genres » [When Nature does not offer the same species, she likes to repeat the same genera]

During his many travels, Alexander von Humboldt was able to observe the floras of many regions of the world with contrasting climates. He noticed that the same grass species could be found in Switzerland or along the Magellan strait, and the same violet occurred on top of the volcano on Tenerife and in the Pyrenees Mountains (Humboldt \& Bonpland, 1814, p. 601). He was puzzled by the possible migration of plants across oceans or areas with an inhospitable climate. He acknowledged that the number of species shared by the Old and New Continents may not be as great as previously thought, but speculated that the highest mountains of tropical America probably have plantains, valerians, sandworts, buttercups, medlars, oaks, and pines that look like the European ones but belong to different species (Humboldt \& Bonpland, 1814, p. 602). Thus, the same genera or closely-related genera belonging to the same tribe (Humboldt \& Bonpland, 1814, p. 602) are to be expected in regions with the same climatic conditions.

Long distance dispersal is now acknowledged as a major force in biogeography (de Queiroz, 2005), and even improbable dispersal between islands in different oceans has been shown (Le Roux et al., 2014). When plants disperse over long distances from continents to islands, they will often occupy areas with similar ecological conditions (Carlquist, $1974 \mathrm{p}$. 81). Lineages have a tendency to retain the same ecological traits or niche characteristics through time and speciation events, which has been termed phylogenetic niche conservatism (Ackerly, 2003; Crisp \& Cook, 2012; Wiens et al., 2010). It has been shown, for example, 
Pillon Y., González D. A., Randriambanona H., Lowry II P. P., Jaffré T., Merlot S. 2019. Parallel ecological filtering of ultramafic soils in three distant island floras. Journal of Biogeography, 46 (11): 2457-2465.

that plants tend to occupy similar biomes after transoceanic dispersal across southern continents (Crisp et al., 2009). The assemblage of a community such as the Mediterraneantype woody vegetation of California (chaparral) involved not only adaptation but also niche conservatism (Ackerly, 2004). Indeed, the small leaves and low specific leaf area of several plant lineages, characteristic of Mediterranean vegetation, are features that were often already present in their ancestors before dispersal from their ancestral subtropical biome. The greater success of lineages that already possess a suitable combination of functional traits for their novel niche has been termed ecological sorting (Ackerly, 2003, 2004).

Evidence for niche conservatism and ecological sorting in plants comes primarily from studies on biome preferences (e.g. Ackerly, 2004; Crisp et al., 2009). These mechanisms are likely to operate in plant responses to edaphic conditions. For example, Stebbins (1974, p. 43) noted a "selective inertia" leading to a preference of Ericaceae for acid soils, Caryophyllaceae for mineral-rich substrates, and Chenopodiaceae for saline or sub-saline soils. Habitat filtering can be expected to be more obvious in extreme environments such as on ultramafic substrates. Soils derived from ultramafic rocks (including serpentine) offer challenging conditions for plant development because of their low content in essential nutrients $(\mathrm{N}, \mathrm{P}, \mathrm{K})$, a strong imbalance in their $\mathrm{Mg}$ :Ca ratio, high concentrations of certain metals ( $\mathrm{Ni}, \mathrm{Co}, \mathrm{Cr}$, etc.), and low water availability leading to stress, as well as their fire-prone vegetation (Kazakou, Dimitrakopoulos, Baker, Reeves, \& Troumbis, 2008; Proctor, 2003). Outcrops of ultramafic rocks are often covered with a distinctive vegetation that includes narrowly endemic species, e.g. in California (Safford, Viers, \& Harrison, 2005), Cuba (Borhidi, 1996), and New Caledonia (Wulff et al., 2013). Previous work has suggested that ultramafic substrates may have acted as a filter that could explain the over- or under-representations of certain plant families (i.e. disharmony) on the island of New Caledonia (Pillon, Munzinger, Amir, \& Lebrun, 2010). 
Pillon Y., González D. A., Randriambanona H., Lowry II P. P., Jaffré T., Merlot S. 2019. Parallel ecological filtering of ultramafic soils in three distant island floras. Journal of Biogeography, 46 (11): 2457-2465.

To test the ecological filtering effects of ultramafic substrates, Cuba, Madagascar, and New Caledonia represent an ideal comparative system. Ultramafic outcrops are found on all three islands, which occur in three different oceans and belong to distinct floristic kingdoms or subkingdoms (Takhtajan, 1986). They share very few species and are thus almost totally independent systems, but share more higher rank taxa and are sufficiently diverse to permit a broad sampling of the tree of life. In this insular context, the total pool (i.e. the entire island) from which the ultramafic flora is most likely derived is easily defined and characterized. We have intentionally limited our study to tropical islands, thus excluding temperate floras, to limit possible effects of climate as a filtering factor. In order to see if Humboldt's observation can be expanded to edaphic conditions, we tested whether the same families tended to be selected for or against on the ultramafic substrates of all three islands, and thereby demonstrate whether soil can be a driver of ecological sorting. Assuming that ultramafic floras should be a random subset of the total flora for each island, we measured how each family deviates from this null-model and assessed if their behaviour was consistent between islands.

\section{2 | MATERIAL AND METHODS}

\section{$2.1 \mid$ Model systems}

The southwest Pacific island of New Caledonia has a continental basement that emerged above sea level ca. $37 \mathrm{My}$ ago, when it was covered with ultramafic substrates that now occupy one third $\left(5,470 \mathrm{~km}^{2}\right)$ of the surface of Grande Terre, the main island (Cluzel, Chiron, \& Courme, 1998; Pelletier, 2006). New Caledonia's biota is considered to have reached the island via long-distance dispersal from neighbouring areas, particularly Australasia (Grandcolas et al., 2008). Mount Humboldt (1,617 m), the second highest peak of 
Pillon Y., González D. A., Randriambanona H., Lowry II P. P., Jaffré T., Merlot S. 2019. Parallel ecological filtering of ultramafic soils in three distant island floras. Journal of Biogeography, 46 (11): 2457-2465.

New Caledonia, entirely comprised of ultramafic rocks, is a nature reserve and a major centre of micro-endemism (Bradford \& Jaffré, 2004; Munzinger, McPherson, \& Lowry, 2008).

The island of Cuba emerged 30-35 My ago (Iturralde-Vinent \& MacPhee, 1999; Iturralde-Vinent, 2006), and according to the GAARlandia hypothesis, ancestors of a portion of the terrestrial biota may have colonized the island through a land bridge with South America (Ali, 2012; Iturralde-Vinent \& MacPhee, 1999). Nevertheless, long-distance dispersal seems to have been the dominant source of colonizers among seed plants (NietoBlázquez, Antonelli, \& Roncal, 2017). Ultramafic substrates, recorded on Cuba by Humboldt (1826), cover c. $7 \%\left(2,700 \mathrm{~km}^{2}\right)$ of the island, including areas of ancient origin (10-30 My) in the Western and Eastern regions (Finko, Korin, \& Formell, 1967), while Cuba's central ultramafic area was exposed more recently $(<1 \mathrm{My}$, Zonn, 1968). Alejandro de Humboldt National Park is a UNESCO World Heritage Site in eastern Cuba with great biological and geological diversity, including ultramafic-adapted ecosystems.

Madagascar is a portion of Gondwana that was located between the TanzaniaMozambique coast, India and Antarctica prior to its detachment from the African continent starting at the end of the Jurassic (about $<140 \mathrm{My}$ ), followed by the separation of India in the late Cretaceous (<83 My, Fröhlich, 1996). While a small portion of Madagascar's rich flora may thus have an ancient continental (vicariant) origin, recent reviews indicate that subsequent dispersal has played an important role (Buerki, Devey, Callmander, Phillipson, \& Forest, 2013; Yoder \& Nowak, 2006). Ultramafic soils are rare in Madagascar, but a lateritic nickel deposit occurs at Ambatovy, which covers an area of $12 \times 7 \mathrm{~km}$ at an elevation of approximately 1,000 m above sea level on Madagascar's eastern escarpment (Delbos \& Rantoanina, 1961) and has been dated to c. 89-91 My (Melluso et al., 2005). Botanical inventories of the area were recently conducted and several micro-endemic species have been 
Pillon Y., González D. A., Randriambanona H., Lowry II P. P., Jaffré T., Merlot S. 2019. Parallel ecological filtering of ultramafic soils in three distant island floras. Journal of Biogeography, 46 (11): 2457-2465.

reported (Phillipson, Lowry, Andriamahefaviro, Antilahimena, \& Birkinshaw, 2010), most of which have now been also found in surrounding areas (Madagascar Catalogue, 2019).

\section{2 | Data sets}

For the flora of New Caledonia, we used the list of native species occurring on ultramafic substrates from Isnard et al. (2016) and the complete checklist of the indigenous flora from FLORICAL (Morat et al., 2012, updated ; Munzinger et al., 2016). For the flora of Madagascar, we used the plant checklist from the Ambatovy-Analamay region (Phillipson et al., 2010), the main ultramafic outcrop of the island, and the complete checklist from the Madagascar Catalogue (Callmander et al., 2011; Madagascar Catalogue, 2019 accessed 15/09/2016) taking into account only native species. In Cuba, we developed a partial checklist of plants (appendix S1 in supporting information) occurring on ultramafic substrate by compiling lists from various regions and sources: Guamuhaya (Glaría, González-Torres, Iturralde, \& Granados, 2006) Lomas de Galindo (Lara, Lópes García, Garcia, \& Iturralde, 1999; Robledo, Ortega, \& Rodríguez, 2009), Yamanigüey (Valdés, Rodríguez, \& Iturralde, 1986), Central Cuba (Franco, Herrera, Castañeda, Noa, \& Oviedo, 2016), and the Oriental Region of Cuba (Quesada, 2011). We removed synonyms and non-native species using Greuter \& Rodríguez (2016), which also served as a checklist for the entire Cuban flora. Our analyses were restricted to flowering plants.

\section{3 | Representation indices}

To quantify the under- or over-representation of plant families, we defined a representation index. For each plant family and each island, we first calculated the expected number of species $\left(\mathrm{N}_{\text {exp,i }}\right)$ that should be observed on ultramafic substrates if they represented a random subset of the entire flora. 
Pillon Y., González D. A., Randriambanona H., Lowry II P. P., Jaffré T., Merlot S. 2019. Parallel ecological filtering of ultramafic soils in three distant island floras. Journal of Biogeography, 46 (11): 2457-2465.

$N_{\text {exp }, i}=N_{T, i} \cdot \frac{M_{u m}}{M_{T}}$,

where $\mathrm{N}_{\mathrm{T}, \mathrm{i}}$ is the total number of species of family $\mathrm{i}$ on the island, $\mathrm{M}_{\mathrm{um}}$ is the total number of species across all families on ultramafic substrates, and $\mathrm{M}_{\mathrm{T}}$ is the total number of species across all families on the island. A representation index $\left(\mathrm{R}_{\mathrm{i}}\right)$ was calculated for each family, as follows (neglog transformation):

$$
R_{i}=\operatorname{sign}\left(N_{o b s, i}-N_{\text {exp }, i}\right) \cdot \ln \left(1+\left|N_{o b s, i}-N_{\text {exp }, i}\right|\right)
$$

where $N_{\text {obs,i }}$ is the observed number of species in family $i$ on ultramafic substrate. $R_{i}$ is positive for over-represented families and negative for under-represented families. The more the number of species observed in a family deviates from expectation, the larger the absolute value of the index is. Representation indices were calculated in the same way for each angiosperm order.

We also identified the families that were significantly under- or over-represented by comparing their number of species on ultramafic substrates compared to that expected under a null hypothesis where the flora on this substrate was a random subset of the entire island flora. We tested deviation from a normally distributed sampling, applying a Bonferroni correction for multiple tests.

\section{4 | Phylogenetic patterns}

Since closely related families are expected to be similar in many ways, spurious correlations between characters can be inferred if families are treated as independent replicates. To circumvent this bias, Felsenstein (1985) introduced a method called pairwise independent contrasts. It involves the comparison of the variables ( $\mathrm{X}$ and $\mathrm{Y})$ between two lineages ( 1 and 2) descending from the same node and the calculation of contrasts $\left(\mathrm{X}_{2}-\mathrm{X}_{1} ; \mathrm{Y}_{2}-\mathrm{Y}_{1}\right)$. Contrasts are calculated for pairs of lineages that descend from the same node, but are phylogenetically 
Pillon Y., González D. A., Randriambanona H., Lowry II P. P., Jaffré T., Merlot S. 2019. Parallel ecological filtering of ultramafic soils in three distant island floras. Journal of Biogeography, 46 (11): 2457-2465.

independent. A positive correlation between contrasts indicates a positive correlation between $\mathrm{X}$ and $\mathrm{Y}$, free of phylogenetic bias. Such an approach requires knowledge of phylogenetic relationships between families. We used the family-level phylogenetic tree of the angiosperms from Magallón et al. (2015), which includes 366 of 416 currently recognized plant families, representing over $99 \%$ of global angiosperm species diversity and over $97 \%$ of each of the three floras investigated. This tree was also simplified to build a tree of angiosperm orders. Pairwise independent contrasts of the representation indices between the three possible island pairs were calculated using PHYLOCOM 4.2 (Webb, Ackerly, \& Kembel, 2008).

\subsection{Concordance between all three islands}

Independent contrasts cannot be used to compare three variables. To test concordance between representation of families on the three islands considered, we classified the families naturally present on all of them in four categories, those that have more species than expected on all three islands, on two islands, on a single island, or on none (i.e. under-represented on all islands). We compared this to a null-model distribution, where under- and overrepresentation is completely independent between islands. For example, if the proportions of under-represented families in Cuba, Madagascar, and New Caledonia are 0.3, 0.5 and 0.46, the expected proportion of families under-represented on all three islands should be $0.3 \times 0.5$ $\times 0.46=0.1403$. We compared the observed distribution and the distribution under the nullmodel using a $\chi^{2}$ test. Note that this approach is not free of phylogenetic effects, contrary to independent contrasts.

\section{3 | RESULTS}


Pillon Y., González D. A., Randriambanona H., Lowry II P. P., Jaffré T., Merlot S. 2019. Parallel ecological filtering of ultramafic soils in three distant island floras. Journal of Biogeography, 46 (11): 2457-2465.

Between 115 and 136 plant families included in the phylogenetic analysis of Magallón et al. (2015) were shared between pairs of the three islands examined, viz. Cuba, Madagascar and New Caledonia. The relationships between contrasts of representation indices of the floras for each island pair are plotted in Figure 1. Within sister family pairs, the better represented family (based on number of species) on ultramafic substrates on a given island was generally also better represented on ultramafics on the other island, a situation observed in a significant proportion of family pairs (table 1). When we compared orders, we also found a significant relationship between representation indices on each island pair. When we compared the 120 families that were represented on all three islands, more often than expected by chance, these families were over- or under-represented on ultramafic substrates on all three islands $\left(\chi^{2}=9.017, \mathrm{p}=0.029\right.$, Figure 2$)$. Fabaceae, Malvaceae, and Poaceae were under-represented on all three islands, and significantly so on Madagascar and New Caledonia (Appendix S2 \& S3). Clusiaceae and Erythroxylaceae were over-represented on all three islands, and significantly so in Madagascar and Cuba. The same pattern was observed among the 46 orders represented on Cuba, Madagascar and New Caledonia, which were overor under-represented on ultramafic substrate on all three islands more often than expected by chance $\left(\chi^{2}=11.777, \mathrm{p}=0.008\right.$, Figure 3$)$.

A group of interest is the COM clade, which comprises the orders Celastrales, Oxalidales, and Malpighiales (figure 3). These three orders are over-represented on all three islands and the clade contains an important number of families that are over-represented on ultramafic substrates on some or all three islands. As a whole, this group has an excess of species on ultramafic substrate, compared to random expectation, of 56\% in Madagascar, $50 \%$ in Cuba, and 10\% in New Caledonia. 
Pillon Y., González D. A., Randriambanona H., Lowry II P. P., Jaffré T., Merlot S. 2019. Parallel ecological filtering of ultramafic soils in three distant island floras. Journal of Biogeography, 46 (11): 2457-2465.

\section{4 | DISCUSSION}

This study indicates that the same plant families tend to be over-represented (e.g. Clusiaceae, Phyllanthaceae, Salicaceae) or under-represented (e.g. Acanthaceae, Fabaceae, Malvaceae, Acanthaceae) on the ultramafic substrates of Cuba, Madagascar, and New Caledonia. This pattern was also observed at higher levels, as the same orders tended to be over- or under-represented on ultramafic substrates of the three islands. The phylogenetic signal observed here is rather deep considering that it can be detected at the family and ordinal levels. Indeed, molecular clocks (Magallón et al., 2015) indicate that most angiosperm families are older than the biota of Cuba or New Caledonia and most of that of Madagascar.

Our comparison involves three islands with a high rate of endemism, each located in a different biogeographical setting. It seems unlikely that direct dispersal from ultramafic substrate on one island to another, could account for more than a small portion of the taxonomic similarities between these communities. Recruitment from the local pool of species appears more likely, which suggests that ecological sorting processes (Ackerly, 2003) were at play. Some ancestral characteristics of plant families (e.g. exaptation, Ackerly, 2004; Gould \& Vrba, 1982) probably contributed to their greater success on ultramafic substrates on all three islands.

Plants capable of adapting to ultramafic substrates may have descended in most cases from an evolutionary precursor (Marazzi et al., 2012) that belongs to a group in which this adaptation is more likely to evolve. The traits, or exaptation (Gould \& Vrba, 1982), that would confer on a plant a greater success on ultramafic substrates remain to be identified. The constrains of such environment are multiple, including low nutrients, high $\mathrm{Mg}$ :Ca ratio, high concentrations of metals, etc. (Kazakou et al., 2008; Proctor, 2003). Sclerophylly has been associated with drought tolerance and soil nutrient deficiency (Salleo \& Nardini, 2000), and is indeed a common feature in New Caledonia's scrubland (maquis) on ultramafic substrate 
Pillon Y., González D. A., Randriambanona H., Lowry II P. P., Jaffré T., Merlot S. 2019. Parallel ecological filtering of ultramafic soils in three distant island floras. Journal of Biogeography, 46 (11): 2457-2465.

(Read, Sanson, de Garine-Wichatitsky, \& Jaffré, 2006). Recent genetic and genomic studies have revealed in Brassicaceae species that several genes coding for proteins involved in the transport of nutrients (e.g. Ca, Mg, K) and transition metals (e.g. Fe, Ni) are linked to adaptation to serpentine (Arnold et al., 2016; Bradshaw Jr, 2005; Sobczyk, Smith, Pollard, \& Filatov, 2017; Turner, Bourne, Von Wettberg, Hu, \& Nuzhdin, 2010). Among these candidate genes, transporters of the Ferroportin/IREG family were shown to transport Ni in Brassicaceae and some other plant families (Halimaa et al., 2014; Meier et al., 2018; Merlot et al., 2014; Morrissey et al., 2009; Schaaf et al., 2006), and could therefore constitute a link between adaptation to ultramafic soils and Ni hyperaccumulation. The latter qualifies plants that accumulate particular metals in their leaves to levels that may be hundreds or thousands of times greater than is normal for most plants (Reeves et al., 2018). In a majority of cases, this trait has been recorded on ultramafic substrate and could be seen as an extreme case of specialization to these edaphic conditions. Genes involved in metal transport may thus characterise the evolutionary precursors of plants adapted to ultramafic substrates. Most of our knowledge on adaptation to ultramafic substrates and metal hyperaccumulation is derived from the mostly temperate and herbaceous Brassicaceae. Although this family favours ultramafic substrates elsewhere (Europe, California), a preference was not observed on the tropical islands studies here, where the family is poorly represented (less than 10 species on each island). Further studies on the genes involved in metal transport on a phylogenetically broad range of tropical plants would be necessary to draw any broad conclusions.

The COM clade stands out for its over-representation on ultramafic substrates on all three islands. Members of this clade also seem to have a predisposition to become nickel hyperaccumulators (Pillon et al., 2010), a syndrome strongly associated with ultramafic substrates. The COM clade represents just $7.1 \%$ of angiosperm species but $51 \%$ of the known nickel hyperaccumulators ( Reeves et al., 2018, Global hyperaccumulator database, 2018). 
Pillon Y., González D. A., Randriambanona H., Lowry II P. P., Jaffré T., Merlot S. 2019. Parallel ecological filtering of ultramafic soils in three distant island floras. Journal of Biogeography, 46 (11): 2457-2465.

Interestingly, this group is sister to the Cucurbitales-Fabales-Fagales-Rosales clade, also known as the nitrogen-fixing clade (Griesmann et al., 2018; Soltis et al., 1995; Werner, Cornwell, Sprent, Kattge, \& Kiers, 2014), generally under-represented on ultramafic substrates (Figure 3). Their exact relationship is nevertheless not fully resolved (Angiosperm Phylogeny Group IV, 2016; Sun et al., 2015). The ancient divergence between these two large clades could be associated with the rise of contrasting nutritional strategies. Similarly the order Caryophyllales is characterized by a prevalence of sodium hyperaccumulators and the high frequency of halophytes (White et al., 2017). This is in line with a certain evolutionary conservatism of nutritional traits, particularly on nutrient-poor soils, suggested by Verboom et al. (2017). Future studies may identify further physiological features that characterise the large clades within angiosperms, which have mostly been defined based on molecular phylogenetic evidence (Angiosperm Phylogeny Group IV, 2016).

Because of the lack of a robust phylogeny of all angiosperm genera, we could not test whether ecological sorting on ultramafic substrates holds true at the generic level. Nevertheless, it can be noted that Garcinia (Clusiaceae), Phyllanthus (Phyllanthaceae), Psychotria (Rubiaceae), and Weinmannia (Cunoniaceae) are present on ultramafic substrates in Cuba, Madagascar, and New Caledonia, but represented in each case by distinct islandendemic species. Remarkably, nickel hyperaccumulation has been recorded in Psychotria and Phyllanthus on both Cuba and New Caledonia (Reeves, 2003), but has not yet been investigated on Madagascar. Our results thus corroborate the observation made by Humboldt (1814) over two centuries ago that the same genera may be found on different continents under similar ecological conditions. Although Humboldt's comment was mostly inspired by climatic considerations, our study shows that it can be extended to edaphic preferences. Modern comparative approaches enable statistical tests of Humboldt's statement, and future 
Pillon Y., González D. A., Randriambanona H., Lowry II P. P., Jaffré T., Merlot S. 2019. Parallel ecological filtering of ultramafic soils in three distant island floras. Journal of Biogeography, 46 (11): 2457-2465.

genetic studies may identify exaptations that underly ecological sorting at broad biogeographic scales.

\section{ACKNOWLEDGMENTS}

We thank L. Barrabé for help with phylogenetic analyses and R. B. Iturralde for assistance with compiling the bibliography. Peter Linder, Félix Forest, and three anonymous reviewers made helpful comments on previous versions of the manuscript. S.M. and D.A.G. were supported by funding from the CNRS (Defi Enviromics Gene-4-Chem) and from the Cooperation and Cultural Action Service of the French Embassy in Cuba.

\section{DATA AVAILABILITY STATEMENT}

The partial checklist of plants occurring on ultramafic substrate in Cuba is provided in Appendix 1.

Authors' contributions. Y.P. conceived the study and conducted the analyses; D.A.B., H.R., P.P.L. and T.J. contributed data; D.A.B., H.R., P.P.L., S.M., T.J. and Y.P. drafted the manuscript.

\section{SUPPORTING INFORMATION}

Additional supporting information may be found online in the Supporting Information section at the end of the article.

\section{BIOSKETCH}


Pillon Y., González D. A., Randriambanona H., Lowry II P. P., Jaffré T., Merlot S. 2019. Parallel ecological filtering of ultramafic soils in three distant island floras. Journal of Biogeography, 46 (11): 2457-2465.

The authors have broad interest in the ecology, systematics and evolution of the flora of Cuba, Madagascar, and New Caledonia, including the ecosystems on ultramafic soils, their restoration, and metal accumulating plants.

References

Ackerly, D. D. (2003). Community assembly, niche conservatism, and adaptive evolution in changing environments. International Journal of Plant Science, 64(S3), S165-S184.

Ackerly, D. D. (2004). Adaptation, niche conservatism and convergence: comparative studies of leaf evolution in the California chaparral. The American Naturalist, 163(4), 654671.

Ali, J. R. (2012). Colonizing the Caribbean: is the GAARlandia land-bridge hypothesis gaining a foothold. Journal of Biogeography, 39, 431-433.

Angiosperm Phylogeny Group IV. (2016). An update of the Angiosperm Phylogeny Group classification for the orders and families of flowering plants: APG IV. Botanical Journal of the Linnean Society, 181(1), 1-20. doi: 10.1111/boj.12385

Arnold, B. J., Lahner, B., DaCosta, J. M., Weisman, C. M., Hollister, J. D., Salt, D. E., ... Yant, L. (2016). Borrowed alleles and convergence in serpentine adaptation. Proceedings of the National Academy of Sciences, 113(29), 8320-8325. doi: $10.1073 /$ pnas. 1600405113

Borhidi, A. (1996). Phytogeography and vegetation ecology of Cuba. Budapest: Akadémiai Kiadó.

Bradford, J. C., \& Jaffré, T. (2004). Plant species microendemism and conservation of montane maquis in New Caledonia: two new species of Pancheria (Cunoniaceae) from the Roche Ouaième. Biodiversity and Conservation, 13, 2253-2273. doi: 10.1023/B:BIOC.0000047901.33761.3c 
Pillon Y., González D. A., Randriambanona H., Lowry II P. P., Jaffré T., Merlot S. 2019. Parallel ecological filtering of ultramafic soils in three distant island floras. Journal of Biogeography, 46 (11): 2457-2465.

Bradshaw Jr, H. D. (2005). Mutations in CAX1 produce phenotypes characteristics of plants tolerant to serpentine soils. New Phytologist, 167, 81-88.

Buerki, S., Devey, D. S., Callmander, M. W., Phillipson, P. B., \& Forest, F. (2013). Spatiotemporal history of the endemic genera of Madagascar. Botanical Journal of the Linnean Society, 171(2), 304-329.

Callmander, M. W., Phillipson, P. B., Schatz, G. E., Andriambolonera, S., Rabarimanarivo, M. W., Rakotonirina, N., ... Lowry II, P. P. (2011). The endemic and non-endemic vascular flora of Madagascar updated. Plant Ecology and Evolution, 144(2), 121-125.

Carlquist, S. (1974). Island Biology. New York: Columbia University Press.

Cluzel, D., Chiron, M. D., \& Courme, M.-D. (1998). Upper Eocene unconformity and preobduction events in New Caledonia. Comptes-Rendus de l'Académie Des Sciences. Science de La Terre et Des Planètes, 327, 485-491.

Crisp, M. D., Arroyo, M. T. K., Cook, L. G., Gandolfo, M. A., Jordan, G. J., McGlone, M. S., ... Linder, H. P. (2009). Phylogenetic biome conservatism on a global scale. Nature, $458,754-756$.

Crisp, M. D., \& Cook, L. G. (2012). Phylogenetic niche conservatism: what are the underlying evolutionary and ecological causes? New Phytologist, 196(3), 681-694.

de Queiroz, A. (2005). The resurrection of oceanic dispersal in historical biogeography. Trends in Ecology and Evolution, 20(2), 68-73.

Delbos, L., \& Rantoanina, M. (1961). Travaux du bureau géologique $N^{\circ} 160$. Tananarive: Service Géologique.

Felsenstein, J. (1985). Phylogenies and the comparative method. The American Naturalist, 125(1), 1-15.

Finko, V. I., Korin, I. Z., \& Formell, C. F. (1967). Sobre la edad de la cortea del intemperismo y las lateritas de Cuba. Revista Geologica. Academia de Ciencias de Cuba, 1, 29-47. 
Pillon Y., González D. A., Randriambanona H., Lowry II P. P., Jaffré T., Merlot S. 2019. Parallel ecological filtering of ultramafic soils in three distant island floras. Journal of Biogeography, 46 (11): 2457-2465.

Franco, F., Herrera, P., Castañeda, I., Noa, A., \& Oviedo, R. (2016). Motembo, a serpentine center of plant evolution in Cuba and the West Indies. Metodos En Ecología i Systemática, 11(3), 51-74.

Fröhlich, F. (1996). La position de Madagascar dans le cadre de l'évolution géodynamique et de l'environnement de l'océan Indien. In W. R. Lourenço (Ed.), Biogéographie de Madagascar (pp. 19-26). Paris: Société de Biogéographie-Muséum-ORSTOM.

Glaría, A. V., González-Torres, L. R., Iturralde, R. B., \& Granados, E. B. (2006). Flora de la región ultramáfica (serpentinícola) de Guamuhuya. Revista Del Jardin Botánico Nacional, 27, 75-84.

Gould, S. J., \& Vrba, E. S. (1982). Exaptation-a missing term in the science of form. Paleobiology, 8(1), 4-15.

Grandcolas, P., Murienne, J., Robillard, T., Desutter-Grandcolas, L., Jourdan, H., Guilbert, E., \& Deharveng, L. (2008). New Caledonia: a very old Darwinian island? Philosophical Transactions of the Royal Society of London B, 363, 3309-3317.

Greuter, W., \& Rodríguez, R. R. (2016). The spermatophyta of Cuba: a preliminary checklist. Berlin: Botanischer Garten und Botanishes Museum Berlin-Dahlem.

Griesmann, M., Chang, Y., Liu, X., Song, Y., Haberer, G., Crook, M. B., ... Cheng, S. (2018). Phylogenomics reveals multiple losses of nitrogen-fixing root nodule symbiosis. Science, 361(6398), 144+. doi: 10.1126/science.aat1743

Halimaa, P., Lin, Y.-F., Ahonen, V. H., Blande, D., Clemens, S., Gyenesei, A., ... Tervahauta, A. I. (2014). Gene expression differences between Noccaea caerulescens ecotypes help to identify candidate genes for metal phytoremediation. Environmental Science \& Technology, 48(6), 3344-3353. doi: 10.1021/es4042995

Humboldt, A. von. (1826). Essai politique sur l'île de Cuba. Paris: Librairie de Gide fils. 
Pillon Y., González D. A., Randriambanona H., Lowry II P. P., Jaffré T., Merlot S. 2019. Parallel ecological filtering of ultramafic soils in three distant island floras. Journal of Biogeography, 46 (11): 2457-2465.

Humboldt, A. von, \& Bonpland, A. (1814). Voyage aux régions équinoxiales du nouveau monde. Paris: F. Schoell.

Isnard, S., L'Huillier, L., Rigault, F., \& Jaffré, T. (2016). How did the ultramafic soils shape the flora of the New Caledonian hotspot? Plant and Soil, 403(1-2), 53-76. doi: $10.1007 / \mathrm{s} 11104-016-2910-5$

Iturralde-Vinent, M.A., \& MacPhee, R. D. E. (1999). Paleogeography of the Caribbean region: implications for Cenozoic biogeography. Bulletin of the American Museum of Natural History, 238, 1-95.

Iturralde-Vinent, M. A. (2006). Meso-cenozoic Caribbean paleogeography: implications for the historical biogeography of the region. International Geology Review, 48(9), 791827. doi: $10.2747 / 0020-6814.48 .9 .791$

Kazakou, E., Dimitrakopoulos, P. G., Baker, A. J. M., Reeves, R. D., \& Troumbis, A. Y. (2008). Hypotheses, mechanisms and trade-offs of tolerance and adaptation to serpentine soils: from species to ecosystem level. Biological Reviews, 83, 495-508.

Lara, J. L., Lópes García, P. I., Garcia, E. P., \& Iturralde, R. B. (1999). Recuperación natural de la flora serpentinícola en "Lomas de Galindo": una alternativa de conservación. Revista Del Jardin Botánico Nacional, 20, 31-39.

Le Roux, J., Strasberg, D., Rouget, M., Morden, C. W., Koordom, M., \& Richardson, D. (2014). Relatedness defies biogeography: the tale of two island endemics (Acacia heterophylla and A. koa). New Phytologist, 204(1), 230-242.

Madagascar Catalogue. (2019). Catalogue of the plants of Madagascar. Retrieved from www.tropicos.org/Project/Madagascar

Magallón, S., Gómez-Acevedo, S., Sánchez-Reyes, L. L., \& Hernández-Hernández, T. (2015). A metacalibrated time-tree documents the early rise of flowering plant phylogenetic diversity. New Phytologist, 207(2), 437-453. doi: 10.1111/nph.13264 
Pillon Y., González D. A., Randriambanona H., Lowry II P. P., Jaffré T., Merlot S. 2019. Parallel ecological filtering of ultramafic soils in three distant island floras. Journal of Biogeography, 46 (11): 2457-2465.

Marazzi, B., Ané, C., Simon, M. F., Delgado-Salinas, A., Luckow, M., \& Sanderson, M. J. (2012). Locating evolutionary precursors on a phylogenetic tree. Evolution, 66(12), $3918-3930$.

Meier, S. K., Adams, N., Wolf, M., Balkwill, K., Muasya, A. M., Gehring, C. A., ... Ingle, R. A. (2018). Comparative RNA-seq analysis of nickel hyperaccumulating and nonaccumulating populations of Senecio coronatus (Asteraceae). The Plant Journal, 95(6), 1023-1038. doi: 10.1111/tpj.14008

Melluso, L., Morra, V., Brotzu, P., Tommasini, S., Renna, M. R., Duncan, R. A., ... D’Amelio, F. (2005). Geochronology and petrogenesis of the Cretaceous Antampombato-Ambatovy complex and associated dyke swarm, Madagascar. Journal of Petrology, 46(10), 1963-1996. doi: 10.1093/petrology/egi044

Merlot, S., Hannibal, L., Martins, S., Martinelli, L., Amir, H., Lebrun, M., \& Thomine, S. (2014). The metal transporter PgIREG1 from the hyperaccumulator Psychotria gabriellae is a candidate gene for nickel tolerance and accumulation. Journal of Experimental Botany, 65(6), 1551-1564.

Morat, P., Jaffré, T., Tronchet, F., Munzinger, J., Pillon, Y., Veillon, J. M., \& Chalopin, M. (2012). The taxonomic reference base Florical and characteristics of the native vascular flora of New Caledonia. Adansonia, 34(2), 179-221.

Morrissey, J., Baxter, I. R., Lee, J., Li, L., Lahner, B., Grotz, N., .. Guerinot, M. L. (2009). The ferroportin metal efflux proteins function in iron and cobalt homeostasis in Arabidopsis. The Plant Cell, 21(10), 3326-3338. doi: 10.1105/tpc.109.069401 Munzinger, J., McPherson, G., \& Lowry, P. P. (2008). A second species in the endemic New Caledonian genus Gastrolepis (Stemonuraceae) and its implications for the conservation status of high-altitude maquis vegetation: coherent application of the 
Pillon Y., González D. A., Randriambanona H., Lowry II P. P., Jaffré T., Merlot S. 2019. Parallel ecological filtering of ultramafic soils in three distant island floras. Journal of Biogeography, 46 (11): 2457-2465.

IUCN Red List criteria is urgently needed in New Caledonia. Botanical Journal of the Linnean Society, 157, 775-783.

Munzinger, J., Morat, P., Jaffré, T., Gâteblé, G., Pillon, Y., Tronchet, F., ... Chalopin, M. (2016). FLORICAL: checklist of the vascular indigeneous flora of New Caledonia vers. 22.IV.2016. Retrieved from http://www.botanique.nc/herbier/florical

Nieto-Blázquez, M. E., Antonelli, A., \& Roncal, J. (2017). Historical biogeography of endemic seed plant genera in the Caribbean: Did GAARlandia play a role? Ecology and Evolution, 7(23), 10158-10174. doi: 10.1002/ece3.3521

Pelletier, B. (2006). Geology of the New Caledonia region and its implications for the study of the New Caledonian biodiversity. In C. E. Payri \& B. Richer de Forges (Eds.), Compendium of marine species from New Caledonia (pp. 17-30). Nouméa: Centre IRD de Nouméa.

Phillipson, P. B., Lowry, P. P., Andriamahefaviro, L., Antilahimena, P., \& Birkinshaw, C. (2010). Floristic inventory of the Ambatovy-Analamay mine site and comparison to other sites in Madagascar. In Biodiversity, exploration, and conservation of the natural habitats associated with the Ambatovy project (Malagasy Nature, pp. 44-76). Goodman, S.M., Mass, V.

Pillon, Y., Munzinger, J., Amir, H., \& Lebrun, M. (2010). Ultramafic soils and species sorting in the flora of New Caledonia. Journal of Ecology, 98(5), 1108-1116. doi: 10.1111/j.1365-2745.2010.01689.x

Proctor, J. (2003). Vegetation and soil and plant chemistry on ultramafic rocks in the tropical Far East. Perspectives in Plant Ecology, Evolution and Systematics, 6, 105-124.

Quesada, E. M. (2011). Riqueza de especies y endemismo de la erspermatófitas en las plurisilvas de la Región Oriental de Cuba. Revista Del Jardin Botánico Nacional, 3233, 79-109. 
Pillon Y., González D. A., Randriambanona H., Lowry II P. P., Jaffré T., Merlot S. 2019. Parallel ecological filtering of ultramafic soils in three distant island floras. Journal of Biogeography, 46 (11): 2457-2465.

Read, J., Sanson, G. D., de Garine-Wichatitsky, M., \& Jaffré, T. (2006). Sclerophylly in two contrasting tropical environments: low nutrients vs. low rainfall. American Journal of Botany, 93(11), 1601-1614.

Reeves, R. D. (2003). Tropical hyperaccumulators of metals and their potential for phytoextraction. Plant and Soil, 249, 57-65.

Reeves, R. D., Baker, A. J. M., Jaffré, T., Erskine, P. D., Echevarria, G., \& van der Ent, A. (2018). A global database for plants that hyperaccumulate metal and metalloid trace elements. New Phytologist, 218(2), 407-411. doi: 10.1111/nph.14907

Robledo, A. G., Ortega, L. G., \& Rodríguez, A. E. (2009). Flora i vegetación de "Lomas de Galindo” Canasí, La Habana. Revista Del Jardin Botánico Nacional, 30-31, 39-50.

Safford, H. D., Viers, J. H., \& Harrison, S. P. (2005). Serpentine endemism in the California flora: a database of serpentine affinity. Madroño, 52(4), 222-257.

Salleo, S., \& Nardini, A. (2000). Sclerophylly: Evolutionary advantage or mere epiphenomenon? Plant Biosystems - An International Journal Dealing with All Aspects of Plant Biology, 134(3), 247-259. doi: 10.1080/11263500012331350435

Schaaf, G., Honsbein, A., Meda, A. R., Kirchner, S., Wipf, D., \& von Wirén, N. (2006). AtIREG2 encodes a tonoplast transport protein involved in iron-dependent nickel detoxification in Arabidopsis thaliana roots. Journal of Biological Chemistry, 281(35), 25532-25540. doi: 10.1074/jbc.M601062200

Sobczyk, M. K., Smith, J. A. C., Pollard, A. J., \& Filatov, D. A. (2017). Evolution of nickel hyperaccumulation and serpentine adaptation in the Alyssum serpyllifolium species complex. Heredity, 118(1), 31-41. doi: 10.1038/hdy.2016.93

Soltis, D. E., Soltis, P. S., Morgan, D. R., Swensen, S. M., Mulli, B. C., Dowd, J. M., \& Martin, P. G. (1995). Chloroplast gene sequence data suggest a single origin of the 
Pillon Y., González D. A., Randriambanona H., Lowry II P. P., Jaffré T., Merlot S. 2019. Parallel ecological filtering of ultramafic soils in three distant island floras. Journal of Biogeography, 46 (11): 2457-2465.

predisposition for symbiotic nitrogen-fixation in angiosperms. Proceedings of the National Academy of Science of the USA, 92(7), 2647-2651.

Stebbins, G. L. (1974). Flowering Plants: Evolution above the Species Level. London: Edward Arnold (Publishers) Limited.

Sun, M., Soltis, D. E., Soltis, P. S., Zhu, X., Burleigh, J. G., \& Chen, Z. (2015). Deep phylogenetic incongruence in the angiosperm clade Rosidae. Molecular Phylogenetics and Evolution, 83, 156-166. doi: 10.1016/j.ympev.2014.11.003

Takhtajan, A. L. (1986). Floristic regions of the world. Berkeley: University of California Press.

Turner, T. L., Bourne, E. C., Von Wettberg, E. J., Hu, T. T., \& Nuzhdin, S. V. (2010). Population resequencing reveals local adaptation of Arabidopsis lyrata to serpentine soils. Nature Genetics, 42(3), 260-263. doi: 10.1038/ng.515

Valdés, C. P., Rodríguez, R. R., \& Iturralde, R. B. (1986). Notas sobre la flora y vegetación de la zona de Yamanigüey, Moa, Provincia de Holguín. Revista Del Jardín Botánico Nacional, 7(2), 79-6.

Verboom, G. A., Stock, W. D., \& Cramer, M. D. (2017). Specialization to extremely lownutrient soils limits the nutritional adaptability of plant lineages. The American Naturalist, 189(6), 684-699. doi: 10.1086/691449

Webb, C. O., Ackerly, D. D., \& Kembel, S. W. (2008). Phylocom: software for the analysis of phylogenetic community structure and trait evolution. Bioinformatics, 24(18), 20982900.

Werner, G. D. A., Cornwell, W. K., Sprent, J. I., Kattge, J., \& Kiers, E. T. (2014). A single evolutionary innovation drives the deep evolution of symbiotic N2-fixation in angiosperms. Nature Communications, 5, 4087. doi: 10.1038/ncomms5087 
Pillon Y., González D. A., Randriambanona H., Lowry II P. P., Jaffré T., Merlot S. 2019. Parallel ecological filtering of ultramafic soils in three distant island floras. Journal of Biogeography, 46 (11): 2457-2465.

White, P. J., Bowen, H. C., Broadley, M. R., El-Serehy, H. A., Neugebauer, K., Taylor, A., ... Wright, G. (2017). Evolutionary origins of abnormally large shoot sodium accumulation in nonsaline environments within the Caryophyllales. New Phytologist, 214(1), 284-293. doi: 10.1111/nph.14370

Wiens, J. J., Ackerly, D. D., Pallen, A. P., Anacker, B. L., Buckley, L. B., Cornell, H. V., ... Stephens, P. R. (2010). Niche conservatism as an emerging principle in ecology and conservation biology. Ecology Letters, 13, 1310-1324.

Wulff, A. S., Hollingsworth, P. M., Ahrends, A., Jaffré, T., Veillon, J. M., L’Huillier, L., \& Fogliani, B. (2013). Conservation priorities in a biodiversity hotspot: analysis of narrow endemic plant species in New Caledonia. Plos One, 8(9), e73371.

Yoder, A. D., \& Nowak, M. D. (2006). Has vicariance or dispersal been the predominant biogeographic force in Madagascar? Only time will tell. Annual Review of Ecology, Evolution, and Systematics, 37(1), 405-431. doi:

10.1146/annurev.ecolsys.37.091305.110239

Zonn, S. V. (1968). Osobennosti pochvoobrazovania i glavnie tipi pochv Kubi. 51-152. Moscow. 
Pillon Y., González D. A., Randriambanona H., Lowry II P. P., Jaffré T., Merlot S. 2019. Parallel ecological filtering of ultramafic soils in three distant island floras. Journal of Biogeography, 46 (11): 2457-2465.

Table 1: Results of independent comparisons between representation indices $\left(\mathrm{R}_{\mathrm{i}}\right)$ on Cuba, Madagascar, and New Caledonia.

\begin{tabular}{llllll}
\hline Level & Island 1 & Island 2 & Number of & Total number & $\mathrm{p}$ \\
& & & positive & of independent & \\
& & & contrasts & contrasts & \\
\hline \hline Family & Madagascar & New Caledonia & 85 & 127 & $8.10^{-5}$ \\
\hline Family & Madagascar & Cuba & 83 & 135 & $4.810^{-3}$ \\
\hline Family & New Caledonia & Cuba & 70 & 114 & $9.410^{-3}$ \\
\hline Order & Madagascar & New Caledonia & 35 & 44 & $5.310^{-5}$ \\
\hline Order & Madagascar & Cuba & 33 & 46 & $2.310^{-3}$ \\
\hline Order & New Caledonia & Cuba & 31 & 45 & $810^{-3}$ \\
\hline \hline
\end{tabular}


Pillon Y., González D. A., Randriambanona H., Lowry II P. P., Jaffré T., Merlot S. 2019. Parallel ecological filtering of ultramafic soils in three distant island floras. Journal of Biogeography, 46 (11): 2457-2465.

Figure 1. Relationships between contrasts (differences between sister families) of representation indices on ultramafic substrates between each island pair. Points above the $\mathrm{x}$ axis represent a positive association.
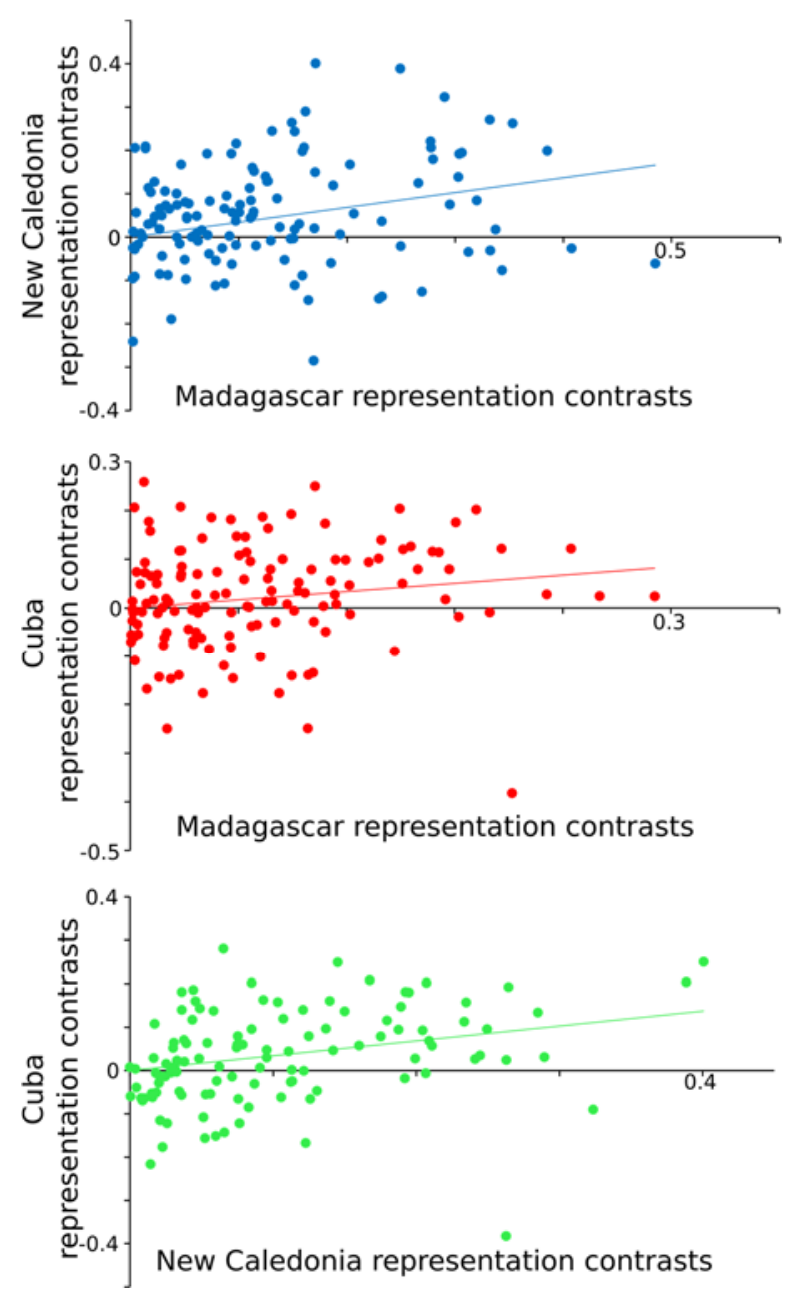
Pillon Y., González D. A., Randriambanona H., Lowry II P. P., Jaffré T., Merlot S. 2019. Parallel ecological filtering of ultramafic soils in three distant island floras. Journal of Biogeography, 46 (11): 2457-2465.

Figure 2. Representation on ultramafic substrates of 120 plant families present on all three islands (Cuba, Madagascar, and New Caledonia). Families tended to respond accordingly more often than expected by chance.

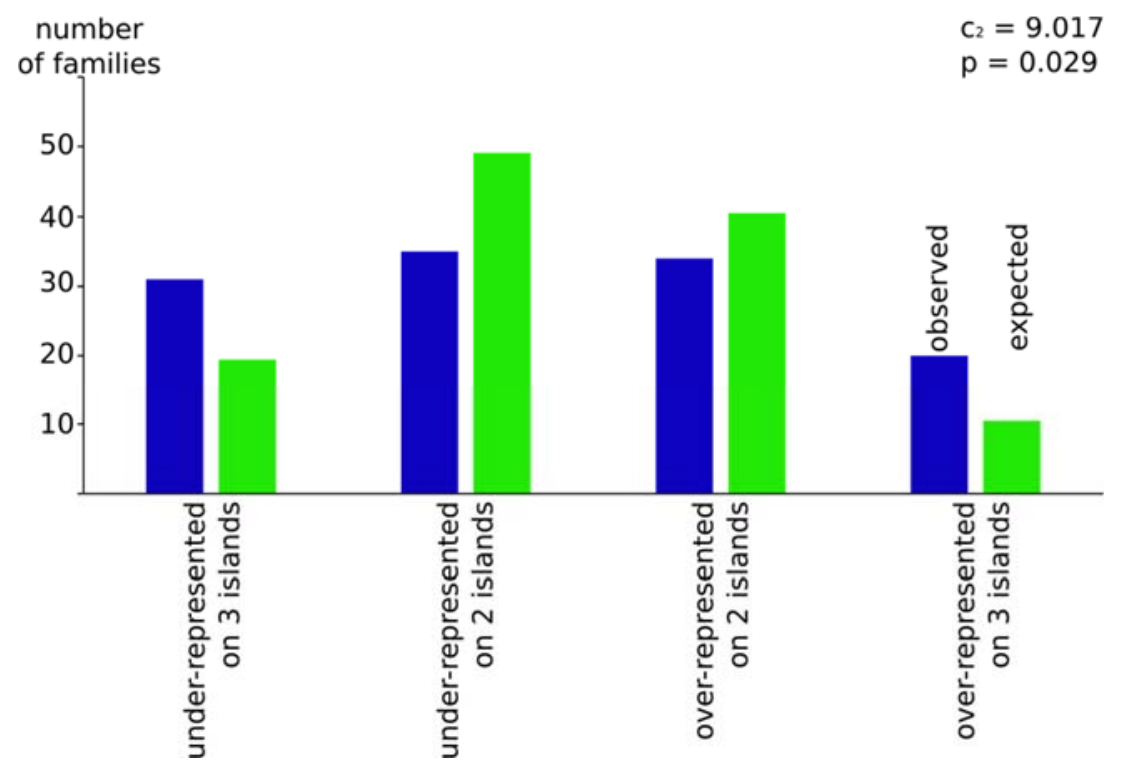


Pillon Y., González D. A., Randriambanona H., Lowry II P. P., Jaffré T., Merlot S. 2019. Parallel ecological filtering of ultramafic soils in three distant island floras. Journal of Biogeography, 46 (11): 2457-2465.

Figure 3. Phylogenetic patterns in under- and over-representation on the ultramafic substrates of Cuba, Madagascar, and New Caledonia. Excesses or deficits in the number of species for each order compared to a null model are mapped on the phylogenetic tree of Magallón et al. (2015). The orders Acorales, Petrosaviales, Trochodendrales, Berberidopsidales, Bruniales (absent on all three islands) and Metteniusales (not included in Magallón et al., 2015) are not shown. The shaded branch corresponds to the COM clade (Celastrales, Oxalidales, Malpighiales). The photograph shows Phyllanthus peltatus (Phyllanthaceae, Malpighiales) on ultramafic substrate in New Caledonia.

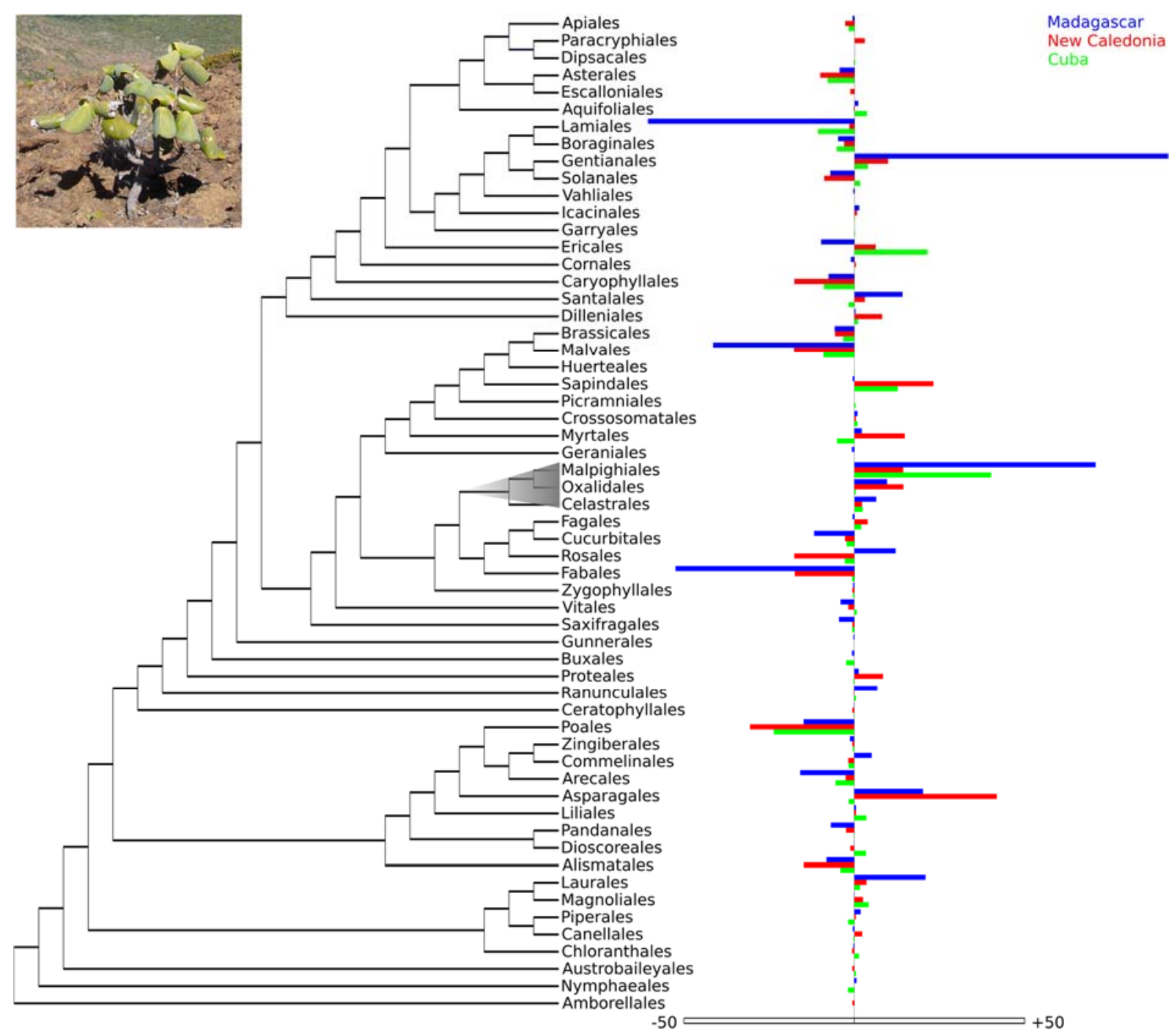

